\title{
Fertilization of Red Maple (Acer rubrum) and Littleleaf Linden (Tilia cordata) Trees at Recommended Rates Does Not Aid Tree Establishment
}

\author{
Susan D. Day and J. Roger Harris
}

\begin{abstract}
Landscape trees typically grow slowly for several years after transplanting. We investigated whether fertilization could speed tree growth during this establishment period, which fertilization regimes were most effective, and whether fertilization interacted with irrigation. Fifty-four each of landscape-sized, balled-and-burlapped red maple (Acer rubrum) and littleleaf linden (Tilia cordata) were planted into a relatively infertile silt loam soil and were fertilized (1.5 kg N/100 $\mathrm{m}^{2}\left[3 \mathrm{lb} \mathrm{N} / 1000 \mathrm{ft}^{2}\right]$ ) each spring (either including or not including at planting), each fall, or not fertilized. Each of these fertilizer regimes was either irrigated or not irrigated during 3 years. An additional treatment of an unirrigated, split (spring/fall) fertilizer application was included. There was no evidence that fertilization affected irrigated trees differently than unirrigated trees. Overall, fertilization did not speed establishment and did not affect trunk growth, shoot extension, or leaf nitrogen content. There was no evidence that fall fertilization might be more effective than spring fertilization. There was no indication that fertilized trees experienced increased drought stress. Nitrogen rates and factors affecting fertilizer uptake are discussed.
\end{abstract}

Key Words. Fertilization; nitrogen; transplanting; tree establishment; urban forestry; urban soils.

Newly planted trees, until they have established and put on significant growth, provide few of the economic, environmental, and aesthetic benefits expected from landscape trees. In this study, we considered whether fertilization could hasten the establishment process, thus accelerating a newly planted tree's entry into the more environmentally productive phases of its life. Tree fertilization has been studied for many years but with ambiguous results (see Struve 2002 for a general review). Fertilization research to date does not provide the definitive answers needed to make fertilization recommendations for newly transplanted trees, especially balledand-burlapped (B \& B) trees and those planted in the lessthan-ideal soils found in urban areas. Whitcomb and his colleagues studied tree response to fertilizer during establishment. Eleven species of bare-root trees showed no growth response to nitrogen during establishment, although leaves of fertilized trees were visibly darker green in the second year (Shoup et al. 1981). Silver maple, a highly vigorous species, grew more rapidly with increased nitrogen when planted in a good clay loam soil but had no response when planted on a poor site with nutrient-deficient silt loam soil (Schulte and Whitcomb 1975). After these mixed results, Whitcomb recommended fertilizing lightly at planting (Whitcomb 1984). Kelting et al. (1998a) found that fertilizing small bare-root trees at planting had little effect on growth in a relatively infertile silt loam soil, and plants were not harmed by quickrelease fertilizers at $14.5 \mathrm{~g} \mathrm{~N} / \mathrm{m}^{2}\left(3 \mathrm{lb} \mathrm{N} / 1000 \mathrm{ft}^{2}\right)$. Neely (1980) found that established trees in fertile soil received only a small benefit from fertilization. In a recent study on two urban sites in Milan, Italy, fertilization increased photosynthesis rate of Japanese pagoda tree (Styphnolobium japonicum) and sweetgum (Liquidambar styraciflua) but not European ash (Fraxinus excelsior) during the first year (Ferrini and Baietto 2006). In subsequent years, this effect disappeared or was reversed and in no case was growth affected by fertilizer. The variable results of past studies have led many practitioners to recommend no fertilization at planting (although little is actually known about when during the first few years after planting that fertilization may speed establishment). As a result, there is much controversy about fertilization at planting and during establishment, and many arborists and urban foresters are hesitant to fertilize at these times. Harris et al. (2004) recommend that trees not be fertilized at planting except in nutrient-deficient soils and that quick-release fertilizers placed in the planting hole should be avoided. Others suggest very low rates of slow-release fertilizer at planting (0 to $4.9 \mathrm{~g} \mathrm{~N} / \mathrm{m}^{2}$ [0 to $\left.1 \mathrm{lb} \mathrm{N} / 1000 \mathrm{ft}^{2}\right]$ ) (Gill et al. 2001). The revised American National Standards Institute (ANSI) standard for tree care operations recommends slow-release fertilizers for new transplants (an earlier version 
recommended no fertilization) (ANSI 1998, 2004). A rate of between 2 and $4 \mathrm{lb} \mathrm{N} / 1000 \mathrm{ft}^{2}$ ( 9.8 to $19.5 \mathrm{~g} / \mathrm{m}^{2}$ ) for slowrelease (half that rate for quick-release) is recommended to address a defined objective in established trees. Even if not harmful to the plant, unnecessary fertilizer is obviously not cost-effective and raises concerns of degrading water resources through runoff or nitrogen leaching.

As extensive research in turfgrass and row crops has shown, the timing and rate of fertilizer application is critical to produce the healthiest and most productive plants as economically as possible and without harming the environment (Petrovic 1990; Cassman et al. 2002; Easton and Petrovic 2004). Arborists, however, have little information available to guide fertilization decisions. Prescription (also known as prescriptive) fertilization (adding nutrients to correct an identified deficiency) may be useful for mature trees (Chacalo 2000; Lilly 2001). Many mature trees presumably also derive nutrients from the fertilization of lawns with which they share rooting space, although this has not been documented. The needs of newly planted trees, however, cannot be addressed in these ways. Furthermore, the physiological disruption caused by transplanting (root severance and loss, desiccation, vessel embolism) may affect tree response to added nutrients.

Trees, especially those in urban areas, often appear to languish for many years before their roots can acquire adequate water and nutrients to sustain significant growth. One area of research interest is whether fertilizer can be effectively used to improve the nutrient status of trees during this period and hasten their entry into the environmentally productive phase of their life. In this study, we evaluate the benefit of fertilization of newly transplanted landscape trees and the effect of fertilizer timing during the establishment period. Our objectives were:

1. To determine if increases in plant growth can be realized through early fertilization;
2. To determine if spring or fall fertilization is more effective;

3. To determine if early fertilization interacts with typical transplant stress caused by lack of irrigation; and

4. To compare the effectiveness of fertilizing at planting to fertilizing after one growing season.

\section{METHODS}

\section{Treatments and Experimental Design}

Fifty-four landscape-sized, field-grown, seedling-grown B \& $\mathrm{B}$ trees each of red maple (Acer rubrum) and littleleaf linden (Tilia cordata) were obtained from Willow Springs Nursery (Christiansburg, VA, U.S.) and transplanted on 24 March 2000 at the Urban Horticulture Research Center in Blacksburg, Virginia. The soil at the research center is a Groseclose silt loam soil (clayey, mixed, mesic Typic Hapludults) with $\mathrm{pH} 6.2$ and a native $\mathrm{N}$ content of approximately $1350 \mathrm{mg}$ $\mathrm{N} / \mathrm{kg}$ of soil $(0.0216 \mathrm{oz} \mathrm{N} / \mathrm{lb}$ of soil) total Kjeldahl nitrogen typical of the relatively infertile soils of the region. Average height and caliper (standard error mean in parentheses) at planting were $3.6(0.09) \mathrm{m}(11.9[0.3] \mathrm{ft})$ and $4.19(0.10) \mathrm{cm}$ (1.7 [0.04] in), respectively, for red maples and $2.69(0.04) \mathrm{m}$ $(8.9[0.13] \mathrm{ft})$ and $4.66(0.06) \mathrm{cm}(1.9[0.02] \mathrm{in})$ for lindens. Trees of each species were placed $2.7 \mathrm{~m}(9 \mathrm{ft})$ apart into one of nine treatments arranged in a completely random design. Treatments were structured as an augmented factorial (Lentner and Bishop 1993) with irrigation and fertilizer regime as factors and an unirrigated, split-application treatment as the augmented treatment (Table 1). Treatments included (1) fertilized each spring and at planting and irrigated (FSPI); (2) fertilized each spring except at planting and irrigated (FSI); (3) fertilized each fall and irrigated (FFI); (4) not fertilized, but irrigated (NFI); (5) fertilized each spring and at planting and not irrigated (FSP); (6) fertilized each spring except at planting and not irrigated (FS); (7) fertilized each fall and not

Table 1. Abbreviations for experimental treatments applied to littleleaf linden and red maple trees.

\begin{tabular}{|c|c|c|c|c|c|c|c|}
\hline \multirow[b]{2}{*}{$\begin{array}{l}\text { Treatment } \\
\text { abbreviations }\end{array}$} & \multirow[b]{2}{*}{$\begin{array}{l}\text { Irrigation } \\
\text { status }\end{array}$} & \multicolumn{6}{|c|}{ Fertilizer application time } \\
\hline & & $\begin{array}{l}\text { At } \\
\text { planting }\end{array}$ & $\begin{array}{l}\text { Fall } \\
2000\end{array}$ & $\begin{array}{l}\text { Spring } \\
2001\end{array}$ & $\begin{array}{l}\text { Fall } \\
2001\end{array}$ & $\begin{array}{l}\text { Spring } \\
2002\end{array}$ & $\begin{array}{l}\text { Fall } \\
2002\end{array}$ \\
\hline FSPI & Irrigated & $X^{z}$ & & $\mathrm{X}$ & & $\mathrm{X}$ & \\
\hline FSI & & & & $\mathrm{X}$ & & $\mathrm{X}$ & \\
\hline FFI & & & $\mathrm{X}$ & & $\mathrm{X}$ & & $X$ \\
\hline NFI & & $\ldots \ldots$ & $\ldots$ & - - - no & $-\ldots$ & $-\ldots$ & $-\ldots$ \\
\hline FSP & Unirrigated & $\mathrm{X}$ & & $\mathrm{X}$ & & $\mathrm{X}$ & \\
\hline FS & & & & $\mathrm{X}$ & & $\mathrm{X}$ & \\
\hline FF & & & $X$ & & $\mathrm{X}$ & & $X$ \\
\hline $\mathrm{FSp}$ & & & $1 / 2 X^{y}$ & $1 / 2 X$ & $1 / 2 X$ & $1 / 2 X$ & $1 / 2 X$ \\
\hline NF & & $-\ldots$ & - . - . & - - - no & 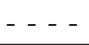 & $-\ldots$ & $-\ldots$ \\
\hline
\end{tabular}


irrigated (FF); (8) fertilized each spring and fall (except at planting) with a split application and not irrigated (FSp); and (9) not irrigated or fertilized (NF). All trees were mulched with shredded hardwood bark in a ring extending approximately $30 \mathrm{~cm}(1 \mathrm{ft})$ beyond the root ball. Rows were maintained weed-free.

Fertilizer applications were broadcast over a $1 \mathrm{~m}^{2}\left(10.8 \mathrm{ft}^{2}\right)$ area centered around each tree at a rate of $1.5 \mathrm{~kg} \mathrm{~N} / 100 \mathrm{~m}^{2}$ $\left(3 \mathrm{lb} \mathrm{N} / 1000 \mathrm{ft}^{2}\right)$ and half that rate for each application in the FSp treatment. The fertilizer was a slow-release, sulfurcoated product from Southern States Cooperative, Inc. (Richmond, VA) with a 27 to $3-12$ analysis $(5.0 \%$ ammoniacal $\mathrm{N}$, $1.8 \%$ water-insoluble $\mathrm{N}, 17.6 \%$ urea $\mathrm{N}$, and $2.6 \%$ other water soluble $\mathrm{N}$ ) described by the manufacturer as having a 4 month release time. Fertilizer was applied according to the treatment as follows: 31 March 2000 (at planting), Sept. 2000 (first fall), April 2001 (second spring), Oct. 2001 (second fall), April 2002 (third spring), and Oct. 2002 (third fall).

All trees were hand watered for 2 weeks after planting. Subsequently, trees in unirrigated treatments received no supplemental water. In each irrigated treatment, soil moisture sensors (Watermark, Irrometer Co. Inc., Riverside, CA, U.S.) were installed $20 \mathrm{~cm}(8 \mathrm{in})$ deep inside and just outside of the root ball of three randomly selected replications. A given treatment was irrigated using drip emitters when soil tension reached $0.055 \mathrm{MPa}$ (55 centibars) on two replications. A replication was considered to have reached this tension when one of the two sensors reached $0.055 \mathrm{MPa}$ (55 centibars). This ensured that trees were irrigated before experiencing drought stress. Rainfall in Blacksburg during the 2000 and 2001 growing seasons was slightly below 30 year norms; for 2002, it was slightly above (Virginia State Climatology Office).

\section{Measurements}

Tree growth and nutrient status were monitored through three growing seasons to ensure that the entire establishment period was studied (Watson 1985). At the end of each growing season, tree caliper readings were taken in two directions, along the row and across the row, and averaged for each tree. Caliper was used to calculate cross-sectional trunk area increase to give an integrated assessment of overall tree growth. Shoot extension during the 2000 and 2001 growing seasons was obtained by measuring new growth in February and March the next year before budbreak. The seven shoots nearest the top that showed the most growth (suppressed shoots, if any, were not included) were measured on each tree. Shoot extension for each replication was taken to be the mean of the remaining five shoots after the two longest shoots were excluded. Foliar nitrogen levels were determined in early summer of the second growing season using four, randomly selected replications of each treatment. We selected five recently matured leaves from separate branches throughout the canopy of each tree selected and pooled them to make one sample. Percent nitrogen content was analyzed using the micro-Kjeldahl method (Peterson and Chesters 1964). To maximize statistical power, only a priori (preplanned) questions of interest were formulated as linear contrasts. These a priori contrasts were analyzed by multivariate repeated measures within the GLM procedure of SAS (version 8; SAS Institute, Cary, NC, U.S.).

\section{RESULTS}

For the most part, fertilization did not affect cross-sectional trunk increase (Figure 1; $P$ values for preplanned contrasts of repeated measures analysis shown in Tables 2 and 3), shoot extension (Figure 2, Tables 2 and 3), or leaf nitrogen content (Tables 2 and 3) of either maples or lindens. Among irrigated treatments, there is no evidence that fertilizer applications affected growth (Tables 2 and 3). Among fertilized treatments, there is little evidence that irrigation affected growth or other variables. Cross-sectional trunk area growth rates and shoot extension were low the first year. This transplant shock effect was most dramatic for lindens (Figures 1 and 2). Repeated measures analysis looks at the growth rate over time (i.e., how size moves through time) and therefore reduces error that might be introduced by differences in initial tree size. Consequently, although spring-fertilized, irrigated red maples appear to have larger cross-sectional areas than other trees, the rate of growth (indicated by the slope of the lines in Figure 1) is similar to other trees (as indicated by the $P$ values in Table 2). In lindens, leaf nitrogen content was higher for FSp trees than in those with other nonirrigated fertilizer regimes $(\mathrm{FSP}=2.39 \%, \mathrm{FF}=2.07 \%, \mathrm{FSP}=$ $2.15 \%, \mathrm{FS}=2.08 \%$ ) as indicated by the contrasts in Table 3 .

The line slope (Figure 1) for FFI red maples between 2000 and 2002 is different from that of other treatments, indicating they grew at a slower rate than other treatments during that period. This is also confirmed by the contrast shown in Table $2(P=0.014)$ between fall and spring fertilization for irrigated red maples. Because FSI red maples show a similar decline in growth rate between 2002 and 2003, however, spring fertilization does not appear to be consistently more effective. Both red maples and lindens with FFI treatment had lower average shoot extension in 2002 than their spring fertilized counterparts; however, these differences are slight and may be the result of factors other than treatment.

\section{DISCUSSION}

The A300 fertilization standard emphasizes that trees should only be fertilized when there is a defined objective. The fertilization objective in this study was to speed the establishment of shade trees. Posttransplant growth of shade trees typically increases annually during the establishment period (Harris and Gilman 1991), so rapid establishment can accel- 


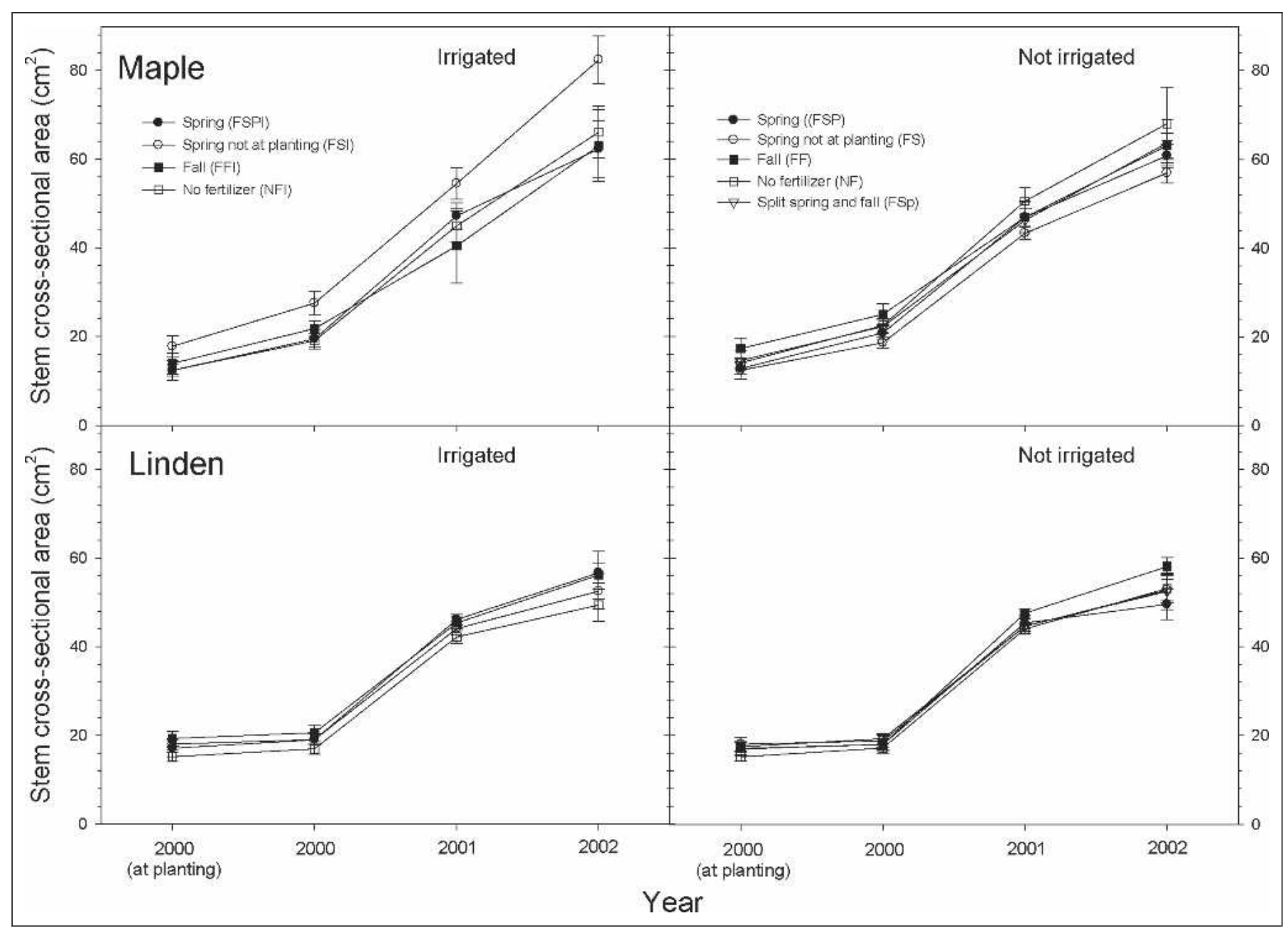

Figure 1. Cross-sectional area of trunk for red maple (Acer rubrum) and littleleaf linden (Tilia cordata) for three growing seasons after transplant under different fertilization and irrigation regimes. Measurements were taken at the end of the growing season except where indicated. Bars indicate standard error of the means of six replications. See Tables 2 and 3 for statistical comparisons.

erate investment return in terms of shade, cooling, carbon sequestration, runoff reduction, and so on. When trees are established, they may no longer need supplemental irrigation. Although there is a defined need in speeding establishment of trees on stressful sites, there is not, at present, a reliable means of achieving this through fertilization.

The total nutrients taken up by the tree from fertilizer is a function of the amount of fertilizer applied and the ability of the plant to absorb these nutrients. Typical fertilizer rates are described on a $\mathrm{N}$ per unit of soil area basis. Ideally, a given rate would provide the plant with sufficient nutrients to achieve a stated management objective while taking into account the plant's ability to absorb these nutrients. When a field-grown tree is dug at the nursery and transplanted, a large part of its root system is lost. This places the tree in the situation of having an aboveground mass that is the same as it was before digging but a root system that is considerably smaller. It may then be virtually impossible to achieve an ideal rate: a "typical" rate may provide far too little fertilizer for the tree (see example subsequently), whereas raising the rate to compensate may overwhelm the ability of the remaining root system to take up nutrients. Although the rate used in this experiment conforms with current recommendations of between 2 and $4 \mathrm{lb} \mathrm{N} / 1000 \mathrm{ft}^{2}$ (9.8 to $19.5 \mathrm{~g} / \mathrm{m}^{2}$ ) (ANSI 2004), this translates into approximately $15 \mathrm{~g}(0.53 \mathrm{oz})$ of actual nitrogen per tree when spread over the rootball area and just beyond $\left(1 \mathrm{~m}^{2}\left[10.8 \mathrm{ft}^{2}\right]\right.$ in the current study). For

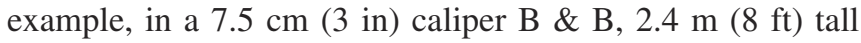
tree, the transplanted root ball is generally $0.71 \mathrm{~m}(2.3 \mathrm{ft})$ in diameter, yielding a rooting ground surface area of $0.4 \mathrm{~m}^{2}$ $\left(4.3 \mathrm{ft}^{2}\right)$ (ANSI 2004). The same size, fully established tree planted in open ground (using the rule of thumb that root 
Table 2. Red maple (Acer rubrum) $P$ values of a priori contrasts for cross-sectional trunk area growth for 3 years after transplanting, shoot extension (mean of five shoots per replication) for 2 years after transplanting, and leaf nitrogen content (pooled sample of five leaves per replication) the third year after transplanting.

\begin{tabular}{|c|c|c|c|c|c|c|}
\hline & $\begin{array}{l}\text { Trunk }^{z} \\
\text { growth } \\
2000\end{array}$ & $\begin{array}{l}\text { Trunk } \\
\text { growth } \\
2001\end{array}$ & $\begin{array}{l}\text { Trunk } \\
\text { growth } \\
2002\end{array}$ & $\begin{array}{l}\text { Shoot }^{\mathrm{y}} \\
\text { extension } \\
2000\end{array}$ & $\begin{array}{l}\text { Shoot } \\
\text { extension } \\
2001\end{array}$ & $\begin{array}{l}\text { Leaf }^{\mathrm{x}} \\
\text { nitrogen } \\
2002\end{array}$ \\
\hline Contrasts & \multicolumn{6}{|c|}{$\mathrm{P}>\mathrm{F}$} \\
\hline Irrigated, fertilized at planting vs. not fertilized at planting (FSPI vs. FSI) & 0.158 & 0.757 & 0.013 & 0.093 & 0.438 & 0.373 \\
\hline Not irrigated, fertilized at planting vs. not fertilized at planting (FSP vs. FS) & 0.339 & 0.598 & 0.959 & 0.562 & 0.392 & 0.209 \\
\hline Irrigated, spring fertilization vs. fall fertilization (FSI vs. FFI) & 0.147 & 0.799 & 0.014 & 0.257 & 0.654 & 0.117 \\
\hline Irrigated, fertilized vs. not fertilized (FSPI, FSI, FFI vs. NFI) & 0.431 & 0.617 & 0.624 & 0.592 & 0.370 & 0.190 \\
\hline Fertilized, irrigated vs. not irrigated (FSPI, FSI, FFI vs. FSP, FS, FF, FSp) & 0.604 & 0.081 & 0.123 & 0.966 & 0.179 & 0.193 \\
\hline Not fertilized, irrigated vs. not irrigated (NFI vs. NF) & 0.362 & 0.418 & 0.495 & 0.717 & 0.065 & 0.612 \\
\hline Not irrigated, spring fertilization vs. $1 / 2$ spring $+1 / 2$ fall (FS vs. FSp) & 0.312 & 0.986 & 0.396 & 0.190 & 0.521 & 0.700 \\
\hline Not irrigated, fall fertilization vs. $1 / 2$ spring $+1 / 2$ fall (FF vs. FSp) & 0.758 & 0.348 & 0.690 & 0.267 & 0.339 & 0.626 \\
\hline Fall fertilization vs. spring fertilization (FSI, FFI vs. FS, FF) & 0.606 & 0.371 & 0.139 & 0.515 & 0.602 & 0.606 \\
\hline
\end{tabular}

${ }^{\mathrm{z}}$ Contrasts are for rate of change from multivariate repeated measures analysis of variance $(n=6)$.

$\mathrm{y}_{n}=6$ with five subsamples per replication.

${ }^{\mathrm{x}}$ Nitrogen content is percent of dry weight $(n=4)$.

spread is 1.5 to 2 times tree height) would have a root system ground surface area between 10.4 and $18.6 \mathrm{~m}^{2}$ (112 to 201 $\mathrm{ft}^{2}$ ). Thus, when fertilization is based on ground surface area of the root system, a tree that has not been transplanted would receive roughly 20 to 40 times as much fertilizer as the same tree after transplanting. One possible reason for the lack of tree response to fertilization in the current study is that the recommended rates simply do not provide a sufficient quantity of fertilizer in this scenario to produce a measurable response.

There is little evidence in the literature of high $\mathrm{N}$ rates damaging transplanted trees. Bare root liners receiving as much as $32.8 \mathrm{~g} \mathrm{~N} / \mathrm{m}^{2}\left(6.7 \mathrm{lb} \mathrm{N} / 1000 \mathrm{ft}^{2}\right)$ did not appear damaged by these high rates; although one of the three species studied did show reduced growth in the first year, this effect disappeared in the second year (Wright and Hale 1983). There is evidence that in some situations, optimum $\mathrm{N}$ application rates for growth of established shade trees may be anywhere from $29.3 \mathrm{~g} \mathrm{~N} / \mathrm{m}^{2}\left(6 \mathrm{lb} \mathrm{N} / 1000 \mathrm{ft}^{2}\right)$ to $58.6 \mathrm{~g} \mathrm{~N} / \mathrm{m}^{2}$ $\left(12 \mathrm{lb} \mathrm{N} / 1000 \mathrm{ft}^{2}\right.$ ) (see Struve's discussion [2002] of research by Neely, Himelick, and Crowley [Neely et al. 1965, 1970]). Gilman et al. (2000) found increases in tree height for container-grown magnolias fertilized in the landscape at a rate of $40 \mathrm{~g} \mathrm{~N} / \mathrm{m}^{2}\left(8.3 \mathrm{lb} \mathrm{N} / 1000 \mathrm{ft}^{2}\right)$ over those fertilized at only 20 $\mathrm{g} \mathrm{N} / \mathrm{m}^{2}\left(4.2 \mathrm{lb} \mathrm{N} / 1000 \mathrm{ft}^{2}\right)$. All of these rates are considerably higher than current recommendations. Nonetheless, there are

Table 3. Littleleaf linden (Tilia cordata) $\boldsymbol{P}$ values of a priori contrasts for cross-sectional trunk area growth for 3 years after transplanting, mean shoot extension (mean of five shoots per replication) for 2 years after transplanting, and leaf nitrogen content (pooled sample of five leaves per replication) the third year after transplanting.

\begin{tabular}{|c|c|c|c|c|c|c|}
\hline & $\begin{array}{l}\text { Trunk }^{z} \\
\text { growth } \\
2000 \\
\end{array}$ & $\begin{array}{l}\text { Trunk } \\
\text { growth } \\
2001 \\
\end{array}$ & $\begin{array}{l}\text { Trunk } \\
\text { growth } \\
2002 \\
\end{array}$ & $\begin{array}{l}\text { Shoot }^{\mathrm{y}} \\
\text { extension } \\
2000 \\
\end{array}$ & $\begin{array}{l}\text { Shoot } \\
\text { extension } \\
2001 \\
\end{array}$ & $\begin{array}{l}\text { Leaf }^{x} \\
\text { nitrogen } \\
2002 \\
\end{array}$ \\
\hline Contrasts & \multicolumn{6}{|c|}{$\mathrm{P}>\mathrm{F}$} \\
\hline Irrigated, fertilized at planting vs. not fertilized at planting (FSPI vs. FSI) & 0.308 & 0.288 & 0.569 & 0.558 & 0.184 & 0.880 \\
\hline Not irrigated, fertilized at planting vs. not fertilized at planting (FSP vs. FS) & 0.757 & 0.432 & 0.288 & 0.222 & 0.533 & 0.603 \\
\hline Irrigated, spring fertilization vs. fall fertilization (FSI vs. FFI) & 0.763 & 0.892 & 0.514 & 0.621 & 0.558 & 0.499 \\
\hline Irrigated, fertilized vs. not fertilized (FSPI, FSI, FFI vs. NFI) & 0.588 & 0.793 & 0.362 & 0.716 & 0.343 & 0.433 \\
\hline Fertilized, irrigated vs. not irrigated (FSPI, FSI, FFI vs. FSP, FS, FF, FSp) & 0.333 & 0.084 & 0.276 & 0.240 & 0.160 & 0.251 \\
\hline Not fertilized, irrigated vs. not irrigated (NFI vs. NF) & 0.840 & 0.394 & 0.607 & 0.019 & 0.914 & 0.102 \\
\hline Not irrigated, spring fertilization vs. $1 / 2$ spring $+1 / 2$ fall (FS vs. FSp) & 0.248 & 0.812 & 0.937 & 0.306 & 0.787 & 0.027 \\
\hline Not irrigated, fall fertilization vs. $1 / 2$ spring $+1 / 2$ fall (FF vs. FSp) & 0.336 & 0.036 & 0.470 & 0.701 & 0.547 & 0.021 \\
\hline Fall fertilization vs. spring fertilization (FSI, FFI vs. FS, FF) & 0.725 & 0.212 & 0.360 & 0.916 & 0.840 & 0.574 \\
\hline
\end{tabular}

${ }^{\mathrm{z}}$ Contrasts are for rate of change from multivariate repeated measures analysis of variance $(n=6)$.

${ }^{\mathrm{y}} n=6$ with five subsamples per replication.

${ }^{\mathrm{x}}$ Nitrogen content is percent of dry weight $(n=4)$. 


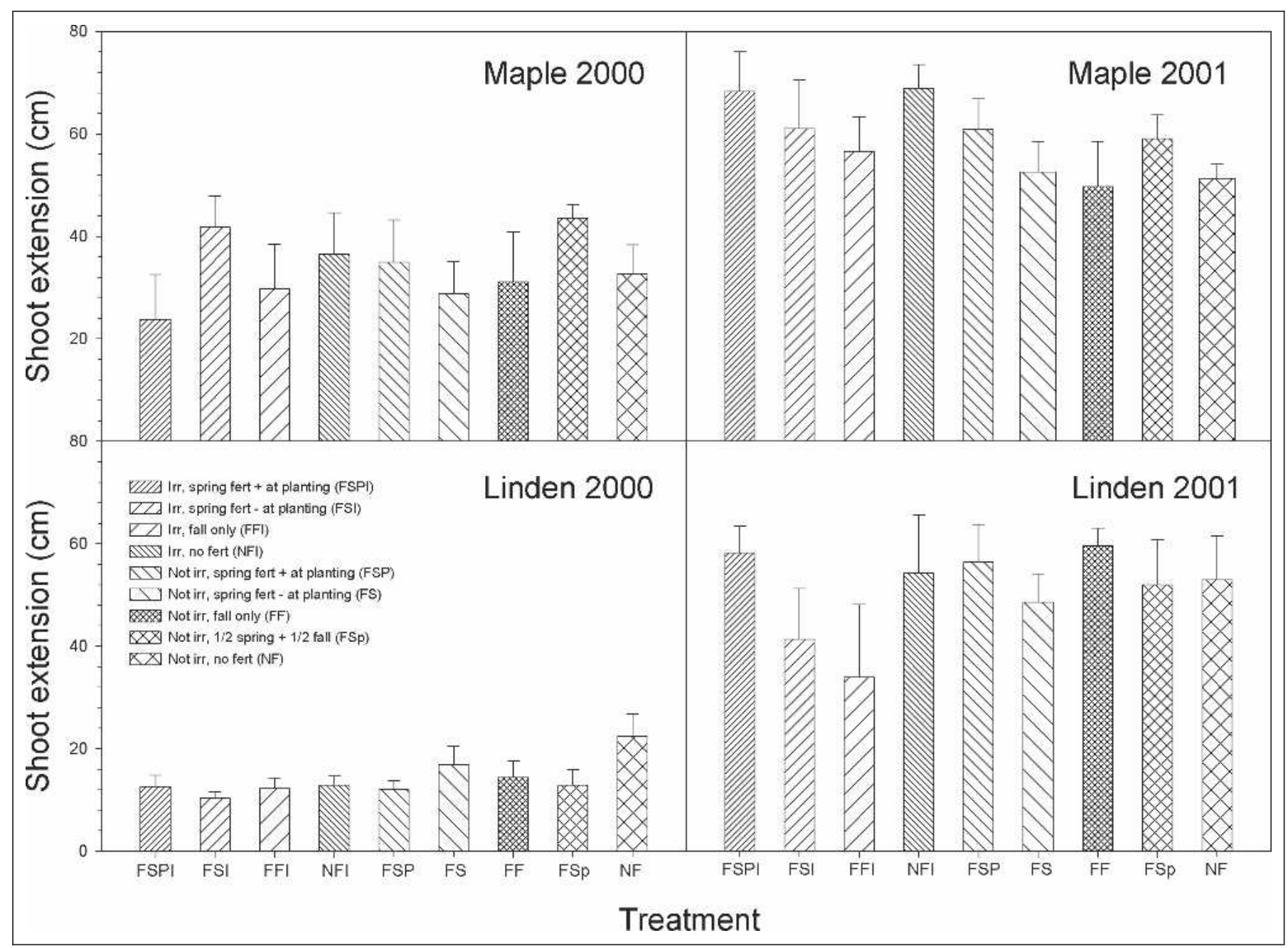

Figure 2. Shoot extension (mean of five shoots per replication) for red maple (Acer rubrum) and littleleaf linden (Tilia cordata) for two growing seasons after transplant under different fertilization and irrigation regimes. Bars indicate standard error of the means for six replications. See Tables 2 and 3 for statistical comparisons.

other impediments to transplanted B \& B trees taking up nitrogen.

Nitrogen uptake by the tree may be suppressed by the root severance that occurs during harvesting and not recover until root regeneration later in the season (Dong et al. 2003). For red maple (Acer rubrum) in Blacksburg, VA, new root growth into the backfill soil may not be visible until 38 days after spring transplant, but other species can take much longer (Kelting et al. 1998b). For example, fringe tree (Chionanthus virginicus) roots may not be visible until 110 days after spring transplant (Harris et al. 1996). Thus, delivery of nutrients to the newly transplanted tree may be hindered by both the reduced physical size of the root system and its physiological state. In the current study, evidence suggests that littleleaf linden and red maple were neither aided nor damaged by fertilizer application. As discussed previously, possible explanations include what is, effectively (on a per tree basis), an extremely low fertilizer rate and of nitrogen uptake reduction caused by root severance that occurred during the transplanting process.

In our study, there was very slight evidence that spring applications of fertilizer might be more effective than fall applications, but this could be the result of the overall lack of effect of any fertilizer regime. In any case, there was certainly no evidence that fall fertilization was more effective than spring. Other work suggests that nitrogen uptake in woody plants is likely better in spring (Aguirre et al. 2001) but may be inhibited temporarily by root severance (Dong et al. 2003). Studies conducted in the same geographic location as this experiment examined root growth of several species, including red maple. Active root growth was typically present slightly before or after budbreak until leaves begin to color for the fall (i.e., the senescence process begins), excluding both hot, dry periods in the summer when root growth is 
negligible and 1 to 3 months into the growing season after transplant (depending on species) (Harris et al. 1995, 1996).

It is unclear whether practitioners can reasonably expect to provide sufficient fertilizer to transplanted B \& B trees through traditional methods and rates. We suggest that further study is merited using higher application rates or other methods (such as foliar application or nutrient loading during nursery production). There is evidence that nutrient loading of container-grown trees at the nursery before harvest can affect growth rates of transplanted trees during the first year (Lloyd et al. 2006). The importance of nitrogen reserves to growth is also apparent in several other studies. In apple trees, reserve nitrogen was found to be a more important determinant of spring shoot flushes than reserve carbohydrates (Cheng and Fuchigami 2002). Dyckmans and Flessa (2001) studied nitrogen mobilization in young beech trees growing in washed sand (labeled $\mathrm{N}$ was provided through nutrient solutions) and concluded that internal nitrogen stores, rather than current supply, had the strongest influence on growth. In the case of B \& B trees, the degree to which nutrient loading might be offset by the loss of much of the root system would also need study.

\section{CONCLUSIONS}

Currently, standards recommend slow-release fertilizer for new transplants and rates comparable to those used in this study. It may be that using nutrients to enhance rapid establishment of B \& B trees can be achieved by other means (different rates, timing of application, or nutrient loading). Current recommendations, however, did not speed establishment for the species studied here. Soil nutrient supply may also be a factor. Although the study site has relatively poor native nitrogen availability as is typical of many urban sites in the mid-Atlantic region of the United States, it is not severely compacted or scraped. There are many sites with more extreme soil conditions-such as disturbed sites where the A (and sometimes B) soil horizons have been removed. Two experiments in progress will examine fertilization at higher rates in soils disturbed by building construction to determine if fertilization can achieve the goal of speeding establishment under these more extreme conditions. At present, however, it appears that other site treatments such as improving overall soil conditions by adding organic matter and reducing compaction (Day et al. 1995) and increasing soil volume (Grabosky and Gilman 2004) may be the most worthwhile investments to speed establishment and long-term growth. Unfortunately, these treatments tend to be more expensive and require planning and coordination, which are often difficult to obtain in urban environments. Our findings from the current study indicate:

1. Current fertilizer rate recommendations do not speed establishment of B \& B red maple and littleleaf linden in moderately poor soil conditions.
2. Fall applications of fertilizer are not more effective than spring applications for red maple and littleleaf linden in these conditions. No fertilization regime improved growth, however, so differences may not be apparent.

3. There was no evidence that fertilizer treatments had negative effects on the growth of unirrigated littleleaf lindens and red maples when compared with irrigated trees, even when rainfall was below average.

\section{IMPLICATIONS FOR ARBORICULTURE}

Research concerning fertilization at planting of balled-andburlapped trees still has not provided definitive answers, and the arboriculture profession should expect recommendations to change as more information becomes available. Fertilizing B \& B trees does not speed establishment under average to moderately poor landscape conditions for littleleaf linden and red maple, whether irrigated or not, in the soil conditions described in this experiment. There may be situations in which fertilization at this time is beneficial, but these have not been fully defined. The results of this study do not provide evidence that fall transplanting is more effective than spring transplanting. Our research further did not suggest that fertilization at transplanting or fertilization of unirrigated trees during establishment will result in tree stress.

Acknowledgments. This research was funded in part by the TREE Fund John Z. Duling Grant Program. We are grateful for this support and for the invaluable technical assistance of Jody Fanelli and John James at the Urban Horticulture

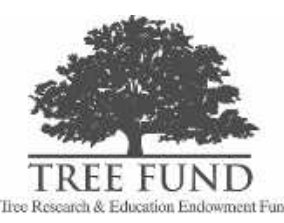
Center of Virginia Tech. We are also grateful to Dr. Dan Ward (former Statistician for the Virginia-Maryland Regional College of Veterinary Medicine, currently Assistant Professor of Horticulture at Rutgers University) for statistical consultation.

\section{LITERATURE CITED}

Aguirre, P.B., Y.K. Al-Hinai, T.R. Roper, and A.R. Krueger. 2001. Apple tree rootstock and fertilizer application timing affect nitrogen uptake. HortScience 36:1202-1205.

American National Standards Institute (ANSI). 1998. ANSI A300 (Part 2) for Tree Care Operations-Tree, Shrub and Other Woody Plant Maintenance-Standard Practices. American National Standards Institute, New York, NY.

—. 2004. ANSI Z60.1 American Standard for Nursery Stock. American Nursery and Landscape Association.

Cassman, K.G., A. Dobermann, and D.T. Walters. 2002. Agroecosystems, nitrogen-use efficiency and nitrogen management. Ambio 31:132-140.

Chacalo, A. 2000. AREA Forum: Why fertilize trees in the urban landscape? Journal of Arboriculture 26:230-232.

Cheng, L., and L.H. Fuchigami. 2002. Growth of young apple trees in relation to reserve nitrogen and carbohydrates. Tree Physiology 22:1297-1303. 
Day, S.D., N.L. Bassuk, and H. van Es. 1995. Effects of four compaction remediation methods for landscape trees on soil aeration, mechanical impedance and tree establishment. Journal of Environmental Horticulture 13:64-71.

Dong, S., L. Cheng, C.F. Scagel, and L.H. Fuchigami. 2003. Root damage affects nitrogen uptake and growth of young Fuji/M.26 apple trees. Journal of Horticultural Science \& Biotechnology 78:410-415.

Dyckmans, J., and H. Flessa. 2001. Influence of tree internal $\mathrm{N}$ status on uptake and translocation of $\mathrm{C}$ and $\mathrm{N}$ in beech: A dual $13 \mathrm{C}$ and $15 \mathrm{~N}$ labeling approach. Tree Physiology 21:395-401.

Easton, Z., and A.M. Petrovic. 2004. Fertilizer source effect on ground and surface water quality in drainage from turfgrass. Journal of Environmental Quality 33:645-655.

Ferrini, F., and M. Baietto. 2006. Response to fertilization of different tree species in the urban environment. Arboriculture \& Urban Forestry 32:93-99.

Gill, S., R. Bosmans, and W. MacLachlan. 2001. Fertilizer Recommendations for Landscape Trees and Shrubs. Maryland Cooperative Extension.

Gilman, E.F., T.H. Yeager, and D. Kent. 2000. Fertilizer rate and type impacts magnolia and oak growth in sandy landscape soil. Journal of Arboriculture 26:177-182.

Grabosky, J., and E.F. Gilman. 2004. Measurement and prediction of tree growth reduction from tree planting space design in established parking lots. Journal of Arboriculture 30:154-159.

Harris, J.R., N.L. Bassuk, R.W. Zobel, and T.H. Whitlow. 1995. Root and shoot growth periodicity of green ash, Turkish hazelnut and tree lilac. Journal of the American Society for Horticultural Science 120:211-216.

Harris, J.R., and E.F. Gilman. 1991. Production method affects growth and root regeneration of Leyland cypress, laurel oak, and slash pine. Journal of Arboriculture 17: 64-69.

Harris, J.R., P. Knight, and J. Fanelli. 1996. Fall transplanting improves establishment of balled and burlapped fringe tree (Chionanthus virginicus L.). HortScience 31: 1143-1145.

Harris, R.W., J.R. Clark, and N.P. Matheny. 2004. Arboriculture: Integrated Management of Landscape Trees, Shrubs, and Vines. Prentice-Hall, Inc., Upper Saddle River, NJ. 578 pp.

Kelting, M., J.R. Harris, J. Fanelli, and B. Appleton. 1998a. Effect of soil amendments and biostimulants on two-year post-transplant growth of red maple and Washington hawthorn. HortScience 33:21-23.

—_. 1998b. Humate-based biostimulants affect early post-transplant root growth and sapflow of red maple. HortScience 33:342-344.

Lentner, M., and T. Bishop. 1993. Experimental Design and Analysis. Valley Book Co., Blacksburg, VA.
Lilly, S. 2001. Arborists' Certification Study Guide. International Society of Arboriculture, Champaign, IL. 222 pp.

Lloyd, J.E., D.A. Herms, M.A. Rose, and J. Van Wagoner. 2006. Fertilization rate and irrigation scheduling in the nursery influence growth, insect performance, and stress tolerance of 'Sutyzam' crabapple in the landscape. HortScience 41:442-445.

Neely, D. 1980. Tree fertilization trials in Illinois. Journal of Arboriculture 6:271-273.

Neely, D., E.B. Himelick, and W.R. Crowley Jr. 1965. Experimental field studies on shade tree fertilization. Illinois Natural History Survey Biological Notes. 53 pp.

- 1970. Fertilization of established trees: A report of field studies. Illinois Natural History Survey Bulletin 30: 235-266.

Peterson, H.C., and G. Chesters. 1964. A reliable total nitrogen determination on plant tissue accumulating nitrate nitrogen. Agronomy Journal 56:89-90.

Petrovic, A.M. 1990. Fate of nitrogenous fertilizers applied to turfgrass. Journal of Environmental Quality 19:1-14.

Schulte, J.R., and C.E. Whitcomb. 1975. Effects of soil amendments and fertilizer levels on the establishment of silver maple. Journal of Arboriculture 1:192-195.

Shoup, S., R. Reavis, and C.E. Whitcomb. 1981. Effects of pruning and fertilizers on establishment of bareroot deciduous trees. Journal of Arboriculture 7:155-157.

Struve, D.K. 2002. A review of shade tree nitrogen fertilization research in the United States. Journal of Arboriculture 28:252-263.

Watson, G.W. 1985. Tree size affects root regeneration and top growth after transplanting. Journal of Arboriculture 11:37-40.

Whitcomb, C.E. 1984. Reducing stress and accelerating growth of landscape plants. Journal of Arboriculture 10: $5-7$.

Wright, R.D., and E.B. Hale. 1983. Growth of three shade tree genera as influenced by irrigation and nitrogen rates. Journal of Environmental Horticulture 1:5-6.

Susan D. Day (corresponding author)

Research Assistant Professor

Department of Forestry

Virginia Polytechnic Institute and State University

228 Cheatham Hall

Blacksburg, VA 24061, U.S.

sdd@vt.edu

J. Roger Harris

Associate Professor

Department of Horticulture

Virginia Polytechnic Institute and State University

301 Saunders Hall

Blacksburg, VA 24061, U.S.

rharris@vt.edu 
Résumé. Les arbres ornementaux poussent typiquement plus lentement durant plusieurs années après leur transplantation. Nous avons vérifié si la fertilisation peut accélérer la croissance de l'arbre durant cette période d'établissement, quel régime de fertilisation est le plus efficace et de quelle manière la fertilisation interagit avec l'irrigation. Cinquante-quatre sujets d'érable rouge (Acer rubrum) et de tilleul à petites feuilles (Tilia cordata) de bonne taille en motte ont été plantés dans un loam limoneux relativement infertile et ont été par la suite été fertilisés-à raison de $1,5 \mathrm{~kg}$ d'azote par $\mathrm{m}^{2}$ - ou non à chaque printemps ou automne. Chacun de ces régime de fertilisation a aussi été accompagné ou non d'une irrigation durant trois ans. Un traitement additionnel sans irrigation avec fertilisation divisée entre printemps et automne a aussi été appliqué. Il n'y a pas eu d'évidence à l'effet que la fertilisation affectait différemment les arbres irrigués de ceux non irrigués. Globalement, la fertilisation n'a pas permis d'accélérer le processus de reprise ni la croissance du tronc ou des pousses, et n'a pas affecté le contenu en azote foliaire. Il n'y a pas eu d'évidence à l'effet que la fertilisation d'automne pourrait être plus efficace que celle au printemps. Il n'y a pas eu d'indication à l'effet que les arbres fertilisés ont souffert d'un stress hydrique accrû. Les taux d'azote ainsi que les facteurs affectant l'assimilation de l'engrais sont discutés.

Zusammenfassung. Bäume wachsen für einige Jahre nach der Verpflanzung sehr langsam. Wir untersuchten, ob Düngung während der Anwachsphase das Wachstum beschleunigen kann, welche Düngemethoden erfolgreich sind und ob Düngung mit Bewässerung interagiert. Je 54 Rotahorne und Winterlinden, in mittlerer Größe, balliert, wurden in einen relativ unfruchtbaren tonigen Lehmboden gepflanzt und wurden entweder jedes Frühjahr (während oder nach der Pflanzung) gedüngt $\left(1,5 \mathrm{~kg} \mathrm{~N} / 100 \mathrm{~m}^{2}\right)$ oder die Düngung erfolgte im Herbst oder gar nicht. Jeder dieser Dün- geversuche wurde über drei Jahre entweder gewässert oder nicht. Eine zusätzliche Behandlung mit einer unbewässerten, gesplitteten Düngung (Frühjahr/Herbst) wurde in die Untersuchung einbezogen. Es gab keinen Beweis, dass die Düngung bewässerte Bäume mehr beeinflusst als unbewässerte Bäume. Gesamt betrachtet beschleunigte die Düngung weder den Anwachsprozess, noch hatte es Einfluss auf Wachstum, Trieblänge oder Stickstoffgehalt. Es gab keinen Beweis, dass Herbstdüngung effektiver als Frühjahrsdüngung war. Es gab auch keine Anzeichen, dass gedüngte Bäume mehr Stress mit Trockenheit hätten. Stickstoffraten und die Faktoren zur Düngeraufnahme wurden hier diskutiert.

Resumen. Los árboles del paisaje típicamente crecen lentamente por varios años después de trasplantados. Se investigó si la fertilización podría agilizar el crecimiento durante este período de establecimiento, cuáles regímenes de fertilización serían más efectivos, y si la fertilización interactuaba con el riego. Se plantaron 54 maples rojos (Acer rubrum) y tilos (Tilia cordata) de cada tamaño, con bola y arpillados, en un sitio de suelo franco-arcilloso relativamente estéril y fueron fertilizados $\left(1.5 \mathrm{~kg} \mathrm{~N} / 100 \mathrm{~m}^{2}\right.$ (3 lbs N/1000 pie $\left.{ }^{2}\right)$ ) cada primavera (incluyendo y no incluyendo la plantación) y cada otoño, o no fueron fertilizados. Cada uno de estos regimenes de fertilización estuvieron regados y no regados durante tres años. Fue incluido un tratamiento adicional de riego con fertilizante compartido (primavera/otoño). No hubo evidencia de que la fertilización afectó a los árboles regados, diferentemente que los no regados. En general, la fertilización no aligeró el establecimiento y no afectó el crecimiento del tronco, la extensión de los brotes, o el contenido de nitrógeno de la hoja. No hubo evidencia de que la fertilización en el otoño pudiera ser más efectiva que la fertilización de primavera. No hubo indicación de que los árboles fertilizados sufrieran estrés por sequía. Se discuten las tasas de nitrógeno y los factores que afectan la absorción de fertilizantes. 